\title{
Increased Expression of Interleukin-18 in Lenses of Ovariectomized Rats
}

\author{
Noriaki Nagai,* Fumihiko Ogata, Naohito Kawasaki, and Yoshimasa Ito \\ Faculty of Pharmacy, Kinki University; 3-4-1 Kowakae, Higashi-Osaka, Osaka 577-8502, Japan. \\ Received August 31, 2015; accepted October 14, 2015
}

\begin{abstract}
Previous studies showed an increased prevalence of cataracts in postmenopausal women. In this study, we investigated changes in the levels of calcium ion $\left(\mathrm{Ca}^{2+}\right)$ and interleukin (IL)-18, which are factors in cataract development, in the lenses of ovariectomized (OVX) rats, a model of postmenopausal woman. Although the $\mathrm{Ca}^{2+}$ content in the blood of $\mathrm{OVX}$ rats increased 1 month after ovariectomy and subsequently decreased, the $\mathrm{Ca}^{2+}$ content in the lenses was unchanged in OVX rats 1-3 months after ovariectomy. The Ca ${ }^{2+}$-ATPase activity in the lenses of OVX rats peaked 1 month after ovariectomy, and the behavior of $\mathrm{Ca}^{2+}$-ATPase activity in lenses of OVX rats was similar to that of the $\mathrm{Ca}^{2+}$ concentration in the blood. It is possible that hypercalcemia increases the $\mathrm{Ca}^{2+}$ inflow into the lens; however, the enhanced $\mathrm{Ca}^{2+}$-ATPase activity prevents the $\mathrm{Ca}^{2+}$ level from rising. On the other hand, we found that the levels of both IL-18 and interferon (IFN)- $\gamma$ in the lenses of $\mathrm{OVX}$ rats were significantly increased as compared with the lenses of sham (control) rats during the period 1-3 months after surgery. These results suggest that the expression of IFN- $\gamma$ via IL-18 in the lenses of $\mathrm{OVX}$ rats is induced by ovariectomy, and that excessive IL-18 and IFN- $\gamma$ production in the lenses may be related to cataract development in postmenopausal women. These findings support those of previous studies that assessed lens opacification in postmenopausal women.
\end{abstract}

Key words interleukin-18; lens; ovariectomized rat; interferon- $\gamma$; calcium

Cataracts are defined as any alteration in the optical homogeneity of the lens or a decrease in its transparency. ${ }^{1,2}$ Exposure to reactive oxygen species, interleukin (IL) or interferon (IFN) $-\gamma$ induced by UV in sunlight are considered to result in a breakdown of lens homeostasis, resulting in an elevation in the calcium ion $\left(\mathrm{Ca}^{2+}\right)$ content of the lens. This elevated $\mathrm{Ca}^{2+}$ content has been deduced to activate calpain, a $\mathrm{Ca}^{2+}$-dependent protease, leading to an increased degradation of lens proteins, such as crystallin proteins, resulting in an opaque lens. ${ }^{3,4)}$ Therefore, the regulation of $\mathrm{Ca}^{2+}$ levels in lens is important to prevent opacification. Previous studies have shown an increased prevalence of cataracts in postmenopausal women, and estrogen has been reported to be effective in preventing age-related cataracts. ${ }^{5-8)}$

Estrogen is a hormone that participates in regulating calcium (Ca) levels in the body, and postmenopausal women experience a drop in estrogen secretion. Bone resorption is regulated by estrogen, and a decrease in estrogen level leads to a decrease in vitamin D. Since vitamin D enhances $\mathrm{Ca}^{2+}$ absorption from the small intestine, ${ }^{9-12)}$ postmenopausal women are at greater risk of osteoporosis and hypercalcemia/ hypocalcemia via the dysfunction in $\mathrm{Ca}^{2+}$ regulation due to a chronic reduction in circulating estrogen levels. ${ }^{9-12)}$ This reduced capacity to regulate $\mathrm{Ca}^{2+}$ levels may be related to the onset of cataracts via an increase in $\mathrm{Ca}^{2+}$ levels in the lens. Estrogens are also known to have antioxidant effects ${ }^{13,14)}$ due to direct scavenging of free-radicals ${ }^{15)}$ and upregulation of antioxidative enzymes. ${ }^{16)}$ In postmenopausal patients, peroxidation increases because of the dramatically decreased estrogen levels. In addition, it has been reported that estrogens prevent the expression of IL-18 in mouse uterus. ${ }^{17)}$ On the other hand, we also found that excessive IFN- $\gamma$ via IL-18 results in cataract development. ${ }^{18,19)}$ From these reports, it is possible that IL-18 levels are also increased in the lenses of postmenopausal women, and that enhanced IFN- $\gamma$ via IL-18 may lead to the formation and progression of cataracts. De- spite these findings, there are, to our knowledge, no reports of concerning $\mathrm{Ca}^{2+}$ regulation and IL-18 expression in the lenses of postmenopausal women.

In this study, we investigated changes in $\mathrm{Ca}^{2+}$ levels and IL-18 expression in postmenopausal lenses using ovariectomized (OVX) rats, an animal model of postmenopausal woman.

\section{MATERIALS AND METHODS}

Animals Female Wistar rats, 5 weeks of age, were ovariectomized (OVX rat) or sham operated (Sham rat). All procedures were performed in accordance with the Kinki University Faculty of Pharmacy Committee Guidelines for the Care and Use of Laboratory Animals and the Association for Research in Vision and Ophthalmology resolution on the use of animals in research.

Quantitative Real-Time Reverse Transcription Polymerase Chain Reaction (RT-PCR) Total RNAs were extracted from the lenses of rats at 10,14, and 18 weeks of age $(1,2$, and 3 months after ovariectomy) by the acid guanidium thiocyanate-phenol-chloroform extraction method ${ }^{20)}$ using Trizol reagent (Life Technologies Inc., Rockville, U.S.A.), and the RT reactions were performed using an RNA PCR Kit (AMV Ver 3.0, TaKaRa Bio Inc., Shiga, Japan) according to the manufacturer's instructions. The RT reactions were performed at $42^{\circ} \mathrm{C}$ for $15 \mathrm{~min}$, followed by $5 \mathrm{~min}$ at $95^{\circ} \mathrm{C}$. The PCR reactions were performed using LightCycler FastStart DNA Master SYBR Green I according to the manufacturer's instructions (Roche Diagnostics Applied Science, Mannheim, Germany). The conditions for PCR and the primers used are shown in Table $1{ }^{18)}$ The quantities of the PCR products were measured fluorometrically in a real-time manner using a LightCycler DX 400 (Roche Diagnostics Applied Science, Mannheim, Germany). The differences in the threshold cycles for glyceraldehyde-3-phosphate dehydrogenase (GAPDH) and 
Table 1. Parameters and Sequences of Primers Used for Quantitative RT-PCR Analysis

\begin{tabular}{|c|c|c|c|c|c|}
\hline Primer & Hot start (10 min) & Denaturation $(10 \mathrm{~s})$ & Annealing (10s) & Extension $(5 \mathrm{~s})$ & Sequence $\left(5^{\prime}-3^{\prime}\right)$ \\
\hline IL-18 & $95^{\circ} \mathrm{C}$ & $95^{\circ} \mathrm{C}$ & $53^{\circ} \mathrm{C}$ & $72^{\circ} \mathrm{C}$ & $\begin{array}{l}\text { FOR: CGCAGTAATACGGAGCATAAATGAC } \\
\text { REV: GGTAGACATCCTTCCATCCTTCAC }\end{array}$ \\
\hline IL-18R $\alpha$ & $95^{\circ} \mathrm{C}$ & $95^{\circ} \mathrm{C}$ & $57^{\circ} \mathrm{C}$ & $72^{\circ} \mathrm{C}$ & $\begin{array}{l}\text { FOR: AGCAGAAAGAGACGAGACACTAAC } \\
\text { REV: CTCCACCAGGCACCACATC }\end{array}$ \\
\hline IL-18R $\beta$ & $95^{\circ} \mathrm{C}$ & $95^{\circ} \mathrm{C}$ & $55^{\circ} \mathrm{C}$ & $72^{\circ} \mathrm{C}$ & $\begin{array}{l}\text { FOR: GACCACAGGATTTAACCATTCAGC } \\
\text { REV: AGCAGGACCTAGTGTTGATGATG }\end{array}$ \\
\hline IL-18BP & $95^{\circ} \mathrm{C}$ & $95^{\circ} \mathrm{C}$ & $53^{\circ} \mathrm{C}$ & $72^{\circ} \mathrm{C}$ & $\begin{array}{l}\text { FOR: TTGGTGGGTCCTGCTTCTATATG } \\
\text { REV: GGTCAGCGTTCCATTCAGTG }\end{array}$ \\
\hline Caspase-1 & $95^{\circ} \mathrm{C}$ & $95^{\circ} \mathrm{C}$ & $55^{\circ} \mathrm{C}$ & $72^{\circ} \mathrm{C}$ & $\begin{array}{l}\text { FOR: TGAAGATGATGGCATTAAGAAGGC } \\
\text { REV: CAAGTCACAAGACCAGGCATATTC }\end{array}$ \\
\hline GAPDH & $95^{\circ} \mathrm{C}$ & $95^{\circ} \mathrm{C}$ & $60^{\circ} \mathrm{C}$ & $72^{\circ} \mathrm{C}$ & $\begin{array}{l}\text { FOR: ACGGCACAGTCAAGGCTGAGA } \\
\text { REV: CGCTCCTGGAAGATGGTGAT }\end{array}$ \\
\hline
\end{tabular}

other groups [IL-18, IL-18R $\alpha$, IL-18R $\beta$, IL-18 binding protein (IL-18BP), caspase-1] were used to calculate the levels of mRNA expression.

Measurement of Calcium Content Femur, blood, aqueous humor and lens from rats at 10, 14, and 18 weeks of age (1, 2, and 3 months after ovariectomy) were removed. The femur was boiled for $2 \mathrm{~h}$, dried at room temperature, and then calcined in a muffle furnace KDF S-80 (Sansyo Co., Ltd., Osaka, Japan) at $550^{\circ} \mathrm{C}$ for $48 \mathrm{~h}$. Calcined femur was dissolved in $1 \%$ nitric acid, and the sample solution was filtered through a $0.45 \mu \mathrm{m}$ membrane filter. ${ }^{21)}$ The $\mathrm{Ca}^{2+}$ concentration of the calcined femur was measured using an inductively coupled plasma-atomic emission spectrometer ICPS-7500 (ICP-AES, Shimadzu Corp., Kyoto, Japan). The lenses were homogenized in phosphate-buffered saline $(\mathrm{pH} 7.4)$ on ice. The lens homogenates and blood were centrifuged at $20400 \times \boldsymbol{g}$ for $30 \mathrm{~min}$ at $4^{\circ} \mathrm{C}$, and the supernatants were used for measurements of $\mathrm{Ca}^{2+}$. The $\mathrm{Ca}^{2+}$ concentrations in the blood, aqueous humor and lens were determined by a Ca test kit (Wako Pure Chemical Industries, Ltd., Osaka, Japan). ${ }^{22)}$

Measurement of $\mathbf{C a}^{2+}$-ATPase Activity Lenses from rats at 10,14 , and 18 weeks of age $(1,2$, and 3 months after ovariectomy) were removed. The $\mathrm{Ca}^{2+}$-ATPase activity was analyzed according to our previously report. ${ }^{22)}$ Briefly, $125 \mu \mathrm{L}$ of solution (200 mM KCl, $100 \mathrm{~mm} N$-(2-hydroxyethyl)piperazine$N^{\prime}$-2-ethanesulfonic acid (HEPES), $10 \mathrm{~mm} \mathrm{MgCl}_{2}, 2 \mathrm{~mm}$ ethylene glycol bis(2-aminoethyl ether)- $N, N, N^{\prime}, N^{\prime}$-tetraacetic acid (EGTA) and $2 \mathrm{~mm}$ ATP, pH 7.4) with or without $2.2 \mathrm{~mm} \mathrm{CaCl}_{2}$ was added to each sample $(125 \mu \mathrm{L})$, and the samples were incubated for $1 \mathrm{~h}$ at $37^{\circ} \mathrm{C}$. The reaction was stopped by the addition of trichloroacetic acid, and the absorbance $(660 \mathrm{~nm})$ of the supernatants was measured. $\mathrm{Ca}^{2+}$-ATPase activity containing plasma membrane $\mathrm{Ca}^{2+}$ ATPase and sarco/endoplasmic reticulum $\mathrm{Ca}^{2+}$-ATPase was calculated as the difference in phosphate liberation measured in the presence and absence of $\mathrm{Ca}^{2+}$. Protein levels were determined using a Bio-Rad Protein Assay Kit (Bio-Rad Laboratories, Hercules, U.S.A.). ${ }^{22)}$

Measurement of IL-18 and IFN- $\boldsymbol{\gamma}$ Levels Lenses from rats at 10,14 , and 18 weeks of age $(1,2$, and 3 months after ovariectomy) were homogenized in ultrapure water. The lens homogenates were centrifuged at $200 \times \boldsymbol{g}$ for $10 \mathrm{~min}$ at $4^{\circ} \mathrm{C}$, and the supernatants were used for the measurement of IL-18 and IFN- $\gamma$ levels. ${ }^{18)}$ The IL-18 and IFN- $\gamma$ levels were measured using an Endogen ${ }^{\circledR}$ Rat IL-18 ELISA Kit and Endogen ${ }^{\circledR}$ Rat
IFN $\gamma$ ELISA Kit, respectively, according to the manufacturer's instructions (Invitrogen Corp., Camarillo, CA, U.S.A.). The range of detection for IL-18 was $15.6-1000 \mathrm{pg} / \mathrm{mL}$, and the range of detection for IFN- $\gamma$ was $8-500 \mathrm{pg} / \mathrm{mL}$ in the ELISA Kits. The IL-18 and IFN- $\gamma$ levels in this study were within the detection range. ${ }^{18)}$ The protein levels were analyzed by the method described above.

Image Analysis of Lens Opacification The experiment was performed following previous report. ${ }^{18)}$ The transparency of the rat lenses were monitored by an EAS-1000 equipped with a CCD camera (Nidek, Gamagori, Japan). The outline of the lens image was determined by selecting 4 points on the image, and then the transparent area within the outline and define level were set automatically by the software.

Statistical Analysis All values are presented as the mean \pm standard error of the mean (S.E.M.). Unpaired Student's $t$-test was used to evaluate statistical differences, and multiple groups were evaluated by one-way ANOVA followed by Dunnett's multiple comparison.

\section{RESULTS AND DISCUSSION}

In this study, we investigated the changes in $\mathrm{Ca}^{2+}$ levels and IL-18 expression in OVX rat, and found that the expression of IL-18 is enhanced by ovariectomy.

In order to predict the changes in $\mathrm{Ca}^{2+}$ levels and IL-18 expression in the lenses of postmenopausal women, the selection of the experimental animal is very important. The OVX rat is an accepted female animal model to mimic postmenopausal women. ${ }^{21,23)}$ The OVX procedure promotes bone loss. Following bilateral ovariectomy, serum $\mathrm{Ca}^{2+}$ levels rise and bone mass decreases due to the loss of estrogen. ${ }^{23,24)}$ Therefore, we confirmed the changes in body weight and calcium contents in the bone and blood in Sham and OVX rats 1-3 months after ovariectomy (Table 2$)$. Food intake $(23.0 \pm 0.8 \mathrm{~g} / \mathrm{d} / \mathrm{rat})$ and water consumption $(35.4 \pm 3.9 \mathrm{~mL} / \mathrm{d} / \mathrm{rat})$ by OVX rats were $\mathrm{sim}$ ilar to those of Sham rats at 3 months after ovariectomy (food intake $23.0 \pm 0.8 \mathrm{~g} / \mathrm{d} / \mathrm{rat}$, water consumption $36.1 \pm 1.4 \mathrm{~mL} / \mathrm{d} / \mathrm{rat}$, mean \pm S.E.M., $n=5$ ). However, the body weight of OVX rats was higher than that of Sham rats. The $\mathrm{Ca}^{2+}$ content in the bones of OVX rats decreased following ovariectomy with a level 3 months after ovariectomy approximately $67 \%$ that of Sham rats. On the other hand, the $\mathrm{Ca}^{2+}$ contents in the blood of OVX rats peaked 1 month after ovariectomy, and subse- 
Table 2. Body Weight and Calcium Levels in Bone and Blood of OVX Rats 1-3 Months after Surgery

\begin{tabular}{|c|c|c|c|c|}
\hline & & 1 month & 2 months & 3 months \\
\hline \multirow[t]{2}{*}{ Body weight (g) } & Sham rats & $264 \pm 11$ & $307 \pm 15$ & $343 \pm 17$ \\
\hline & OVX rats & $307 \pm 12 *$ & $349 \pm 18^{* * * *}$ & $390 \pm 13^{*, * *}$ \\
\hline \multirow[t]{2}{*}{ Ca level in bone $(\mathrm{mg} / \mathrm{g})$} & Sham rats & $345 \pm 13$ & $359 \pm 32$ & $344 \pm 54$ \\
\hline & OVX rats & $257 \pm 19 *$ & $228 \pm 30 *$ & $229 \pm 39 *$ \\
\hline \multirow[t]{2}{*}{$\mathrm{Ca}^{2+}$ level in blood $(\mathrm{mg} / \mathrm{dL})$} & Sham rats & $262 \pm 15$ & $268 \pm 13$ & $261 \pm 16$ \\
\hline & OVX rats & $387 \pm 12 *$ & $321 \pm 22 * * *$ & $307 \pm 19 * *$ \\
\hline
\end{tabular}

The data are presented as the mean \pm S.E.M. of 4-7 independent rats. ${ }^{*} p<0.05, v s$. Sham rats for each category. ${ }^{*} p<0.05, v s$. OVX rats 1 month after surgery.
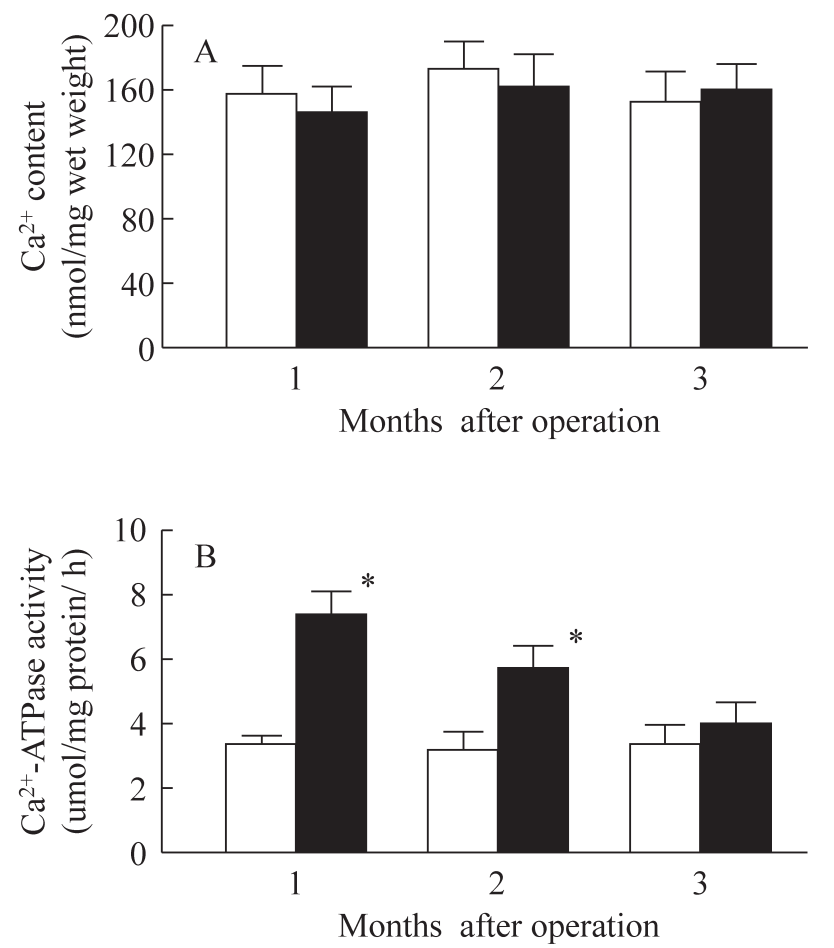

Fig. 1. $\mathrm{Ca}^{2+}$ Content (A) and $\mathrm{Ca}^{2+}$-ATPase Activity (B) in the Lenses of Sham and OVX Rats 1-3 Months after Surgery

The $\mathrm{Ca}^{2+}$ content was measured by the methyl xylenol blue colorimetric method, and is expressed as the ratio of the wet weight of lens. The $\mathrm{Ca}^{2+}$-ATPase activity was calculated as the difference in the phosphate liberation measured in the presence and absence of $\mathrm{Ca}^{2+}$. Open columns, Sham rats; closed columns, OVX rats. The data are presented as the mean \pm S.E.M. of $4-7$ independent rats. $* p<0.05$, vs. Sham rats for each category.

quently decreased. This decrease may be caused by other hormones that regulate $\mathrm{Ca}^{2+}$ levels in the body, such as calcitonin and parathyroid hormone, and these changes in the biological characteristics correspond to those seen in postmenopausal women. These results are similar to previous reports using OVX rats, ${ }^{21)}$ and show that the OVX rats used in this study were suitable for investigating changes in $\mathrm{Ca}^{2+}$ levels and IL-18 expression in lenses after menopause.

Next, we investigated the effect of hypercalcemia on the $\mathrm{Ca}^{2+}$ content of lenses in OVX rats. Although, the $\mathrm{Ca}^{2+}$ content in the aqueous humor of OVX rats 1 months after ovariectomy $(6.80 \pm 0.83 \mathrm{mg} / \mathrm{L}, n=4)$ was higher than that of Sham rats 1 months after ovariectomy $(2.15 \pm 0.31 \mathrm{mg} / \mathrm{L}, n=4)$, the $\mathrm{Ca}^{2+}$ content in the lenses of OVX rats 1-3 months after ovariectomy did not change (Fig. 1A). It is known that the $\mathrm{Ca}^{2+}$ content in lenses is regulated by $\mathrm{Ca}^{2+}$-ATPase. Therefore, we measured the $\mathrm{Ca}^{2+}$-ATPase activity in the lenses of
Table 3. Expression of IL-18 mRNA in Lenses of OVX and Sham Rats 1-3 Months after Surgery

\begin{tabular}{lllll}
\hline \hline & & \multicolumn{1}{c}{1 month } & \multicolumn{1}{c}{2 months } & \multicolumn{1}{c}{3 months } \\
\hline IL-18 $\left(\times 10^{-4}\right)$ & Sham rats & $8.91 \pm 2.98$ & $8.16 \pm 1.93$ & $8.57 \pm 2.11$ \\
& OVX rats & $36.4 \pm 4.89^{*}$ & $37.2 \pm 5.02^{*}$ & $41.1 \pm 5.80^{*}$ \\
IL-18R $\alpha\left(\times 10^{-4}\right)$ & Sham rats & $1.65 \pm 0.51$ & $1.53 \pm 0.49$ & $1.59 \pm 0.54$ \\
& OVX rats & $3.26 \pm 0.56^{*}$ & $3.95 \pm 0.71 *$ & $4.18 \pm 0.77^{*}$ \\
$\mathrm{IL}-18 \mathrm{R} \beta\left(\times 10^{-3}\right)$ & Sham rats & $1.97 \pm 0.71$ & $2.19 \pm 0.72$ & $1.91 \pm 0.70$ \\
& OVX rats & $2.44 \pm 0.68$ & $2.95 \pm 0.74$ & $3.65 \pm 0.71^{*}$ \\
$\mathrm{IL}-18 \mathrm{BP}\left(\times 10^{-5}\right)$ & Sham rats & $7.55 \pm 1.80$ & $7.46 \pm 1.81$ & $7.95 \pm 1.97$ \\
& OVX rats & $7.16 \pm 1.34$ & $7.69 \pm 1.90$ & $7.70 \pm 1.83$ \\
Caspase-1 $\left(\times 10^{-3}\right)$ & Sham rats & $4.61 \pm 1.17$ & $4.56 \pm 1.05$ & $4.67 \pm 1.09$ \\
& OVX rats & $8.93 \pm 1.26^{*}$ & $10.4 \pm 1.31^{*}$ & $11.7 \pm 1.29 *$ \\
\hline
\end{tabular}

The data are presented as the mean \pm S.E.M. of 4-7 independent rat lenses. ${ }^{*} p<0.05, v s$. Sham rats for each category.

Sham and OVX rats 1-3 months after ovariectomy. The $\mathrm{Ca}^{2+}$ ATPase activity in the lenses of OVX rats peaked 1 month after ovariectomy, and the activities 1 and 2 months after ovariectomy were significantly higher than in Sham rats (Fig. 1B). The changes in the $\mathrm{Ca}^{2+}$-ATPase activity in the lenses of OVX rats were similar to those of the $\mathrm{Ca}^{2+}$ concentration in the blood. From these results, we hypothesize that hypercalcemia may increase the $\mathrm{Ca}^{2+}$ inflow into the lens; however, the enhanced $\mathrm{Ca}^{2+}$-ATPase activity prevents the $\mathrm{Ca}^{2+}$ level from rising.

In this study, we also investigated the expression of IL-18 in the lenses of OVX rats. IL-18, which is a pleiotropic cytokine belonging to the IL-1 family, is expressed as an inactive 24$\mathrm{kDa}$ pro-form that is cleaved by caspase- 1 to an $18-\mathrm{kDa}$ active form (mature IL-18). ${ }^{25,26)}$ The mature IL-18 exerts its effects upon binding to its cognate receptor (IL-18R). ${ }^{27)}$ IL-18R $\alpha, \mathrm{R} \beta$ are the two subunits of IL-18R. ${ }^{27)}$ IL- $18 \mathrm{R} \alpha$ is a low-affinity receptor for IL-18, ${ }^{27)}$ while IL-18R $\beta$ does not bind IL-18 directly; instead the $\beta$ chain increases the IL-18 binding affinity and is necessary for initiating signal transduction in target cells. ${ }^{28)}$ The binding of mature IL-18 to IL-18R leads to the production of IFN $-\gamma^{29)}$ IL-18 and IFN- $\gamma$ play an important role in inflammatory action, ${ }^{25,28)}$ and cause lens opacification. ${ }^{18,19)}$ As compared with Sham rats, the lenses of OVX rats showed high expression levels of the mRNAs for IL-18, IL-18R $\alpha$, IL-18R $\beta$ and caspase-1 (Table 3), and the levels remained high 3 months after ovariectomy. On the other hand, it was known that the IL-18BP was a specific, functional inhibitor of IL-18, which may act as an endogenous inhibitor of circulating IL-18. ${ }^{30)}$ The expression of IL-18BP in OVX and Sham rats was similar 1-3 months after ovariectomy. This result shows that the IL-18BP does not affect the IL-18 activity. 

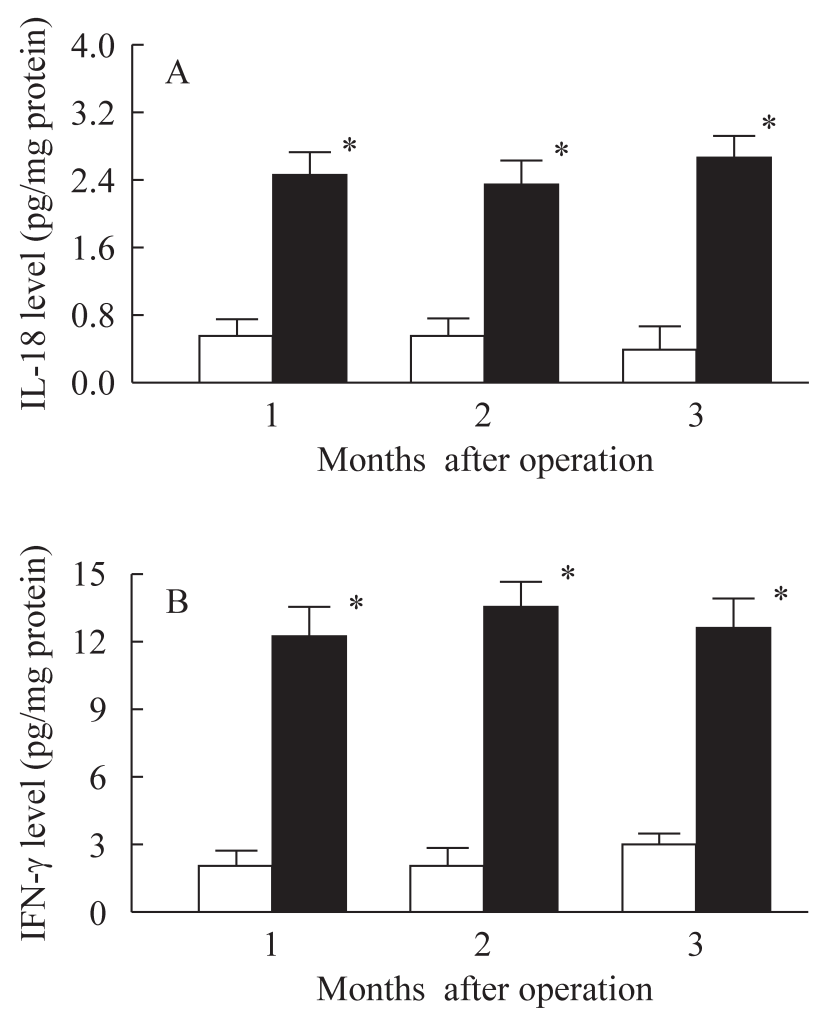

Fig. 2. IL-18 (A) and IFN- $\gamma$ (B) Levels in the Lenses of Sham and OVX Rats 1-3 Months after Surgery

IL-18 and IFN- $\gamma$ levels were determined using an ELISA method. Open columns, Sham rats; closed columns, OVX rats. The data are presented as the mean \pm S.E.M. of 4-7 independent rats. ${ }^{*} p<0.05, v s$. Sham rats for each category.

Figure 2 shows the IL-18 and IFN- $\gamma$ levels determined by the enzyme-linked immunosorbent assay (ELISA) method in the lenses of OVX rats 1-3 months after ovariectomy. No changes in the levels of IL-18 and IFN- $\gamma$ in the lenses of Sham rats were observed, while the IL-18 and IFN- $\gamma$ levels in the lenses of OVX rats were both significantly higher than in the lenses of Sham rats 1-3 months. Three months after ovariectomy, the IL-18 and IFN- $\gamma$ levels in OVX rats were approximately 6.8 and 4.2 times higher than in Sham rats, respectively (Fig. 2).

These results suggest that IL-18 expression was induced in the lenses of OVX rats by the ovariectomy, and that excessive IL-18 and IFN- $\gamma$ production in the lenses may be related to cataract development in postmenopausal women. It has been reported that excessive IFN- $\gamma$ production $(12-20 \mathrm{pg} / \mathrm{mg}$ protein) via IL-18 in the lens cause an increase in the $\mathrm{Ca}^{2+}$ content and opacification. ${ }^{18,19)}$ However, in the OVX rats used in this study, lens opacity was not observed during the period 1-3 months after ovariectomy using EAS-1000. ${ }^{18,19)}$ It was known that the IFN- $\gamma$ production via IL-18 caused the lens epithelial cell damage. ${ }^{31)}$ On the other hand, Harocopos et al. reported that a loss of cells from the lens epithelium, by apoptosis or any other mechanism of cell death, did not seem to play a major role in lens opacification. ${ }^{31)}$ In addition, the elevated $\mathrm{Ca}^{2+}$ content in lenses cause the degradation of crystallin proteins and lens opacification. ${ }^{3,4)}$ Therefore, powerful stimulation or damage by multiple factors (some combination of IL-18 and other factors, such as reactive oxygen species) may be needed to induce the dysfunction of $\mathrm{Ca}^{2+}$ regulation and onset of cataracts. Further studies are needed to elucidate the relationship between IL-18 expression and the development of cataracts in postmenopausal women. In addition, it is important to clarify the mechanism of $\mathrm{Ca}^{2+}$ regulation in the lenses of OVX rats. Therefore, we are now planning to investigate the effects of estrogen on IL-18 expression in the lenses of OVX rats. Moreover, we will demonstrate the effects of calmodulin, which is related to the activity of $\mathrm{Ca}^{2+}$ ATPase, ${ }^{32)}$ on the $\mathrm{Ca}^{2+}$ regulation in the lenses of OVX rats. These results support previous studies that have assessed lens opacification in postmenopausal women. ${ }^{5-8,33)}$

Conflict of Interest The authors declare no conflict of interest.

\section{REFERENCES}

1) Iwata S. Crystalline Lens (Suishotai, in Japanese). (Iwata S ed.) Medical-Aoi Publication Press, Tokyo, Japan, pp. 355-360 (1986).

2) Ye J, Zadunaisky JA. Study of the $\mathrm{Ca}^{2+} / \mathrm{Na}^{+}$exchange mechanism in vesicles isolated from apical membranes of lens epithelium of spiny dogfish (Squalus acanthias) and bovine eye. Exp. Eye Res., 55, 243-250 (1992)

3) Shearer TR, David LL, Anderson RS, Azuma M. Review of selenite cataract. Curr. Eye Res., 11, 357-369 (1992).

4) Dilsiz N, Olcucu A, Atas M. Determination of calcium, sodium, potassium and magnesium concentrations in human senile cataractous lenses. Cell Biochem. Funct., 18, 259-262 (2000).

5) Benitez del Castillo JM, del Rio T, Garcia-Sanchez J. Effects of estrogen use on lens transmittance in postmenopausal women. $\mathrm{Oph}$ thalmology, 104, 970-973 (1997).

6) Wang J, Yan H. Preventive effect of estrogen on cataract development. Yan Ke Xue Bao, 22, 20-24 (2006), Review.

7) Klein BE, Klein R, Ritter LL. Is there evidence of an estrogen effect on agerelated lens opacities? Arch. Ophthalmol., 112, 85-91 (1994).

8) Hales AM, Chamberlain CG, Murphy CR, McAvoy JW. Estrogen protects lenses against cataract induced by transforming growth factor- $\beta$. J. Exp. Med., 185, 273-280 (1997).

9) Ensrud KE, Duong T, Cauley JA, Heaney RP, Wolf RL, Harris E, Cummings SR, Study of Osteoporotic Fractures Research Group. Low fractional calcium absorption increases the risk for hip fracture in women with low calcium intake. Ann. Intern. Med., 132, 345-353 (2000).

10) Tilyard MW, Spears GF, Thomson J, Dovey S. Treatment of postmenopausal osteoporosis with calcitriol or calcium. N. Engl. J. Med., 326, 357-362 (1992).

11) Kubo T, Shiga T, Hashimoto J, Yoshioka M, Honjo H, Urabe M, Kitajima I, Semba I, Hirasawa Y. Osteoporosis influences the late period of fracture healing in a rat model prepared by ovariectomy and low calcium diet. J. Steroid Biochem. Mol. Biol., 68, 197-202 (1999).

12) Montalcini T, Terracciano R, Romeo S, Foti D, Gulletta E, Costanzo FS, Pujia A. Postmenopausal women with carotid atherosclerosis: potential role of the serum calcium levels. Nutr Metab Cardiovasc Dis, 23, 1141-1146 (2013).

13) Mooradian AD. Antioxidant properties of steroids. J. Steroid Biochem. Mol. Biol., 45, 509-511 (1993).

14) Gómez-Zubeldia MA, Arbués JJ, Hinchado G, Nogales AG, Millán JC. Influence of estrogen replacement therapy on plasma lipid peroxidation. Menopause, 8, 274-280 (2001).

15) Ruiz-Larrea MB, Martín C, Martínez R, Navarro R, Lacort M, Miller NJ. Antioxidant activities of estrogens against aqueous and lipophilic radicals: differences between phenol and catechol estrogen. Chem. Phys. Lipids, 105, 179-188 (2000).

16) Borrás C, Gambini J, Gómez-Cabrera MC, Sastre J, Pallardó FV, 
Mann GE, Viña J. 17 $\beta$-Oestradiol up-regulates longevity-related, antioxidant enzyme expression via the ERK1 and ERK2 (-MAPK)/ NFkB cascade. Aging Cell, 4, 113-118 (2005).

17) Murakami Y, Otsuki M, Kusumoto K, Takeuchi S, Takahashi S. Estrogen inhibits interleukin-18 mRNA expression in the mouse uterus. J. Reprod. Dev., 51, 639-647 (2005).

18) Nagai $\mathrm{N}$, Murao $\mathrm{T}$, Ito $\mathrm{Y}$, Okamoto $\mathrm{N}$, Okamura H. Involvement of Interleukin 18 in Lens Opacification of Otsuka long-Evans Tokushima Fatty Rats, a Model of Human Type 2 Diabetes. Curr. Eye Res., 36, 497-506 (2011).

19) Nagai N, Ito Y, Okamura H. Involvement of Interleukin 18 in Cataract Development in Hereditary Cataract UPL Rats. J. Biochem., 142, 597-603 (2007).

20) Nagai N, Ito Y. Excessive hydrogen peroxide enhances the attachment of amyloid $\beta_{1-42}$ in the lens epithelium of UPL rats, a hereditary model for cataracts. Toxicology, 315, 55-64 (2014).

21) Nagai N, Ogata F, Kawasaki N, Ito Y, Funakami Y, Okamoto N, Shimomura Y. Hypercalcemia leads to delayed corneal wound healing in ovariectomized rats. Biol. Pharm. Bull., 38, 1063-1069 (2015).

22) Nagai $N$, Ito $Y$, Takeuchi $N$. Inhibitive effects of enhanced lipid peroxidation on $\mathrm{Ca}(2+)$-ATPase in lenses of hereditary cataract ICR/f rats. Toxicology, 247, 139-144 (2008).

23) Omi N, Ezawa I. The effect of ovariectomy on bone metabolism in rats. Bone, 17 (Suppl.), S163-S168 (1995).

24) Agata U, Park JH, Hattori S, Iimura Y, Ezawa I, Akimoto T, Omi $\mathrm{N}$. The effect of different amounts of calcium intake on bone metabolism and arterial calcification in ovariectomized rats. J. Nutr. Sci. Vitaminol., 59, 29-36 (2013).

25) Ghayur T, Banerjee S, Hugunin M, Butler D, Herzog L, Carter A, Quintal L, Sekut L, Talanian R, Paskind M, Wong W, Kamen R, Tracey D, Allen H. Caspase-1 processes IFN-gamma-inducing fac- tor and regulates LPS-induced IFN-gamma production. Nature, $\mathbf{3 8 6}$, 619-623 (1997)

26) Gu Y, Kuida K, Tsutsui $\mathrm{H}, \mathrm{Ku}$ G, Hsiao K, Fleming MA, Hayashi N, Higashino K, Okamura H, Nakanishi K, Kurimoto M, Tanimoto T, Flavell RA, Sato V, Harding MW, Livingston DJ, Su MS. Activation of interferon-gamma inducing factor mediated by interleukinlbeta converting enzyme. Science, 275, 206-209 (1997).

27) Torigoe K, Ushio S, Okura T, Kobayashi S, Taniai M, Kunikata T, Murakami T, Sanou O, Kojima H, Fujii M, Ohta T, Ikeda M, Ikegami H, Kurimoto M. Purification and characterization of the human interleukin-18 receptor. J. Biol. Chem., 272, 25737-25742 (1997).

28) Kim SH, Reznikov LL, Stuyt RJ, Selzman CH, Fantuzzi G, Hoshino T, Young HA, Dinarello CA. Functional reconstitution and regulation of IL-18 activity by the IL-18R beta chain. J. Immunol., 166, 148-154 (2001).

29) Nakanishi K, Yoshimoto T, Tsutsui H, Okamura H. Interleukin-18 regulates both Th1 and Th2 responses. Annu. Rev. Immunol., 19, 423-474 (2001).

30) Aizawa Y, Akita K, Taniai M, Torigoe K, Mori T, Nishida Y, Ushio S, Nukada Y, Tanimoto T, Ikegami H, Ikeda M, Kurimoto M. Cloning and expression of interleukin-18 binding protein. FEBS Lett., 445, 338-342 (1999).

31) Harocopos GJ, Alvares KM, Kolker AE, Beebe DC. Human agerelated cataract and lens epithelial cell death. Invest. Ophthalmol. Vis. Sci., 39, 2696-2706 (1998).

32) Mandal A, Liyanage MR, Zaidi A, Johnson CK. Interchange of autoinhibitory domain conformations in plasma-membrane $\mathrm{Ca}^{2+}-$ ATPase-calmodulin complexes. Protein Sci., 17, 555-562 (2008).

33) Cumming RG, Mitchell P. Hormone replacement therapy, reproductive factors, and cataract. The Blue Mountains Eye Study. Am. J. Epidemiol., 145, 242-249 (1997). 